\title{
Earthquake risk from co-seismic stress
}

\section{Last year's Indonesian earthquake has increased seismic hazard in the region.}

-

ollowing the massive loss of life caused by the Sumatra-Andaman earthquake in Indonesia and its tsunami, the possibility of a triggered earthquake on the contiguous Sunda trench subduction zone is a real concern. We have calculated the distributions of co-seismic stress on this zone, as well as on the neighbouring, vertical strike-slip Sumatra fault, and find an increase in stress on both structures that significantly boosts the already considerable earthquake hazard posed by them. In particular, the increased potential for a large subduction-zone event in this region, with the concomitant risk of another tsunami, makes the need for a tsunami warning system in the Indian Ocean all the more urgent.

Inspection of the aftershock distribution and evidence from recent inversions reveal that the Sumatra-Andaman earthquake of 26 December 2004 ruptured almost 0.25 million square kilometres of the Indian plate/ Burma microplate subduction zone (Fig. 1), generating a tsunami. The current death toll is in the region of 300,000 .

Subduction-zone earthquakes are often coupled: in the Nankai trough subduction zone to the southeast of Japan, for example, five of the seven large earthquakes on the Nankaido segment in the past 1,500 or so years were accompanied by similar events on the contiguous Tonankai/Tokai segment within five years, and three of those occurred in the same year ${ }^{1}$. This observation is entirely consistent with stress interaction, which has been shown to explain the space-time juxtaposition of large earthquakes ${ }^{2}$. The destructive Izmit earthquake (magnitude 7.4) southeast of Istanbul, for example, was triggered by stress increases of less than 2 bars that were due to earlier local events ${ }^{3}$; in turn, this triggered the Düzce earthquake (magnitude 7.1), which occurred three monthslater.

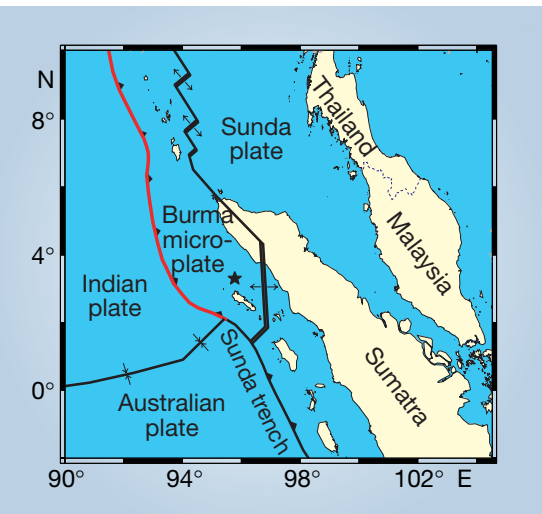

Figure 1 Plate tectonics of the Sumatra region. The red line indicates the southern extent of the surface trace of the SumatraAndaman earthquake rupture. Star, 2004 earthquake epicentre.

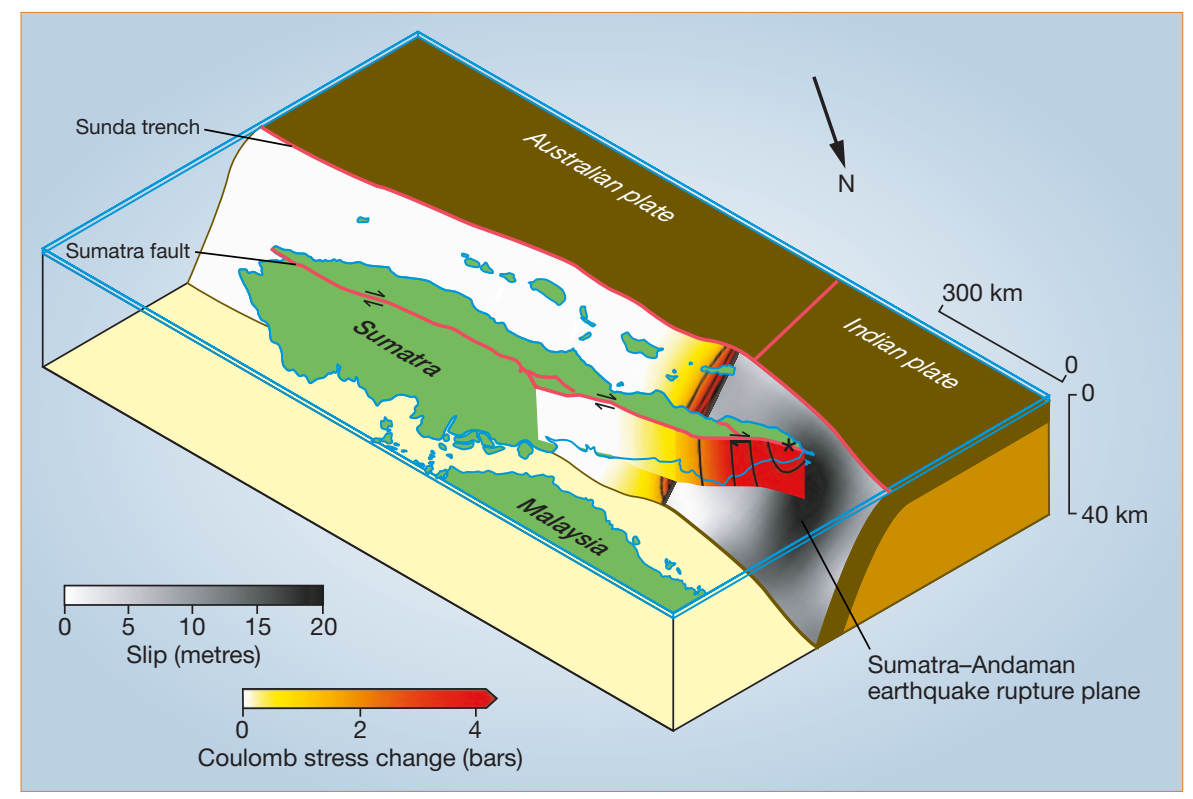

Figure 2 The Sumatran subduction zones with the overlying plates removed. Calculated three-dimensional stresses have been projected on to a diagram of the three-dimensional structural geometry and geography of the region. Grey-scale values on the rupture plane represent the amount of slip in metres experienced on the southernmost $450 \mathrm{~km}$ of the Sumatra-Andaman earthquake. Colour-scale values represent the co-seismic stress changes on the Sunda-trench subduction zone and the Sumatra fault. Stress contours (in black) show 2-bar intervals, starting from a maximum of 8 bars on both faults. Essential features of the calculated stresses are robust to changes in the slip distribution in recent long-period inversions, which show continuation of slip to the north for a total rupture length of about $1,200 \mathrm{~km}$ (ref. 10). Black asterisk indicates location of the devastated Indonesian city of Banda Aceh.

Previous work on the palaeoseismology of the Sunda trench has indicated that this area may already be advanced in the seismic cycle $^{5}$. The northern section of the Sumatra fault has not experienced any large earthquakes for at least the past 100 years either.

Waveform-inversion studies reveal a strongly heterogeneous slip distribution for the Sumatra-Andaman earthquake, with maximum displacements being of the order of $20 \mathrm{~m}$ and the majority of the slip being concentrated on the southernmost $500 \mathrm{~km}$ or so of the rupture ${ }^{6}$. We used this slip distribution to calculate the stress perturbation tensor, which was then resolved on the structures of interest. Results show a stress increase of up to 5 bars in the $50 \mathrm{~km}$ of the Sunda trench next to the rupture zone, but they also show a strong positive loading of up to 9 bars for about $300 \mathrm{~km}$ on the Sumatra fault near the city of Banda Aceh (Fig. 2).

The results indicate that although a subduction-zone event in the Sunda trench has been made more likely by the SumatraAndaman earthquake, at present the increase in stress is localized on the north of this segment. The effect might be expected to spread further south in the months ahead as a result of viscoelastic relaxation in the lower crust, which has not been calculated here $^{7}$. Earthquakes on the Sunda trench in
1833 and 1861 are known to have produced fatal tsunamis ${ }^{8}$.

The co-seismic stress perturbation on the Sumatra fault described here is significantly larger and of a greater spatial extent than the stresses that are believed to have triggered large, strike-slip earthquakes in the North Anatolian Fault Zone $e^{2}$. Considering past activity and the observed structural complexity on the northern Sumatra fault ${ }^{9}$, an earthquake of magnitude 7-7.5 on this structure would seem to represent the greatest immediate threat.

\section{John McCloskey, Suleyman S. Nalbant,}

\section{Sandy Steacy}

School of Environmental Sciences, University of Ulster, Coleraine, County Derry BT52 1SA, UK

e-mail: j.mccloskey@ulster.ac.uk

1. Rydelek, P. A. \& Sacks, I. S. Earth Planet. Sci. Lett. 206, 289-296 (2003).

2. Stein, R. S., Barka, A. A. \& Dieterich, J. H. Geophys. J. Int. 128, 594-604 (1997).

3. Nalbant, S. S., Hubert, A. \& King, G. C. P. J. Geophys. Res. 103, 24469-24486 (1998)

4. Hubert-Ferrari, A. et al. Nature 404, 269-272 (2000).

5. Zachariasen, J., Sieh, K., Taylor, F. W., Edwards, R. L. \& Hantoro W. S. J. Geophys. Res. 104, 895-919 (1999).

6. Ji, C. http://neic.usgs.gov/neis/bulletin/neic slav ff.html (2005). . Pollitz, F. F. \& Sacks, I. S. Bull. Seismol. Soc. Am. 87, 1-10 (1997) 8. Newcomb, K. R. \& McCann, W. R. J. Geophys. Res. 92, 421-439 (1987)

9. Genrich, J. F. et al. J. Geophys. Res. 105, 28327-28341 (2000). 10. Stein, S. \& Okal, E. Nature (in the press).

Competing financial interests: declared none. 